\title{
Early Detection of Pregnancy and Embryonic Loss in Dairy Cattle by ELISA Tests
}

\author{
G Gábor ${ }^{1}$, F Tóth ${ }^{1}$, L Ózsvári ${ }^{2}$, Zs Abonyi-Tóth ${ }^{2}$ and RG Sasser ${ }^{3}$ \\ ${ }^{1}$ Research Institute for Animal Breeding and Nutrition, Herceghalom, Hungary; ${ }^{2}$ Faculty of Veterinary Sciences, SZIE, Budapest, Hungary; \\ ${ }^{3}$ Biotracking LLC, Moscow, ID, USA
}

\section{Contents}

Over a 25 -month period 8118 blood samples were assayed for the presence of the serum pregnancy specific-protein B (PSPB) and progesteron (P4) concentrations on three Hungarian large-scale dairy farms. Pregnancy $(\mathrm{n}=4085)$ was checked by BioPRYN assay at 30-36 days post-insemination (PI). Samples from all cows that tested not pregnant and from cows with an optical density (OD) reading in the BioPRYN test that was between $0 \%$ and $30 \%$ above the cutoff OD value were tested for serum P4 concentration. According to serum P4 concentration, cows were assigned to three categories: high $(>4 \mathrm{ng} / \mathrm{ml})$, medium $(2-4 \mathrm{ng} / \mathrm{ml})$ and low $(<2 \mathrm{ng} / \mathrm{ml})$ serum progesterone. The authors predicted a presumed (low) or possible (medium) late embryonic loss (LEL) or maintenance of the pregnancy (high). A total of 710 LELs were detected $(17.4 \%)$ and $31.8 \%$ of them were predicted because of a low OD value at 30-36 days after insemination. Lower PSPB serum level significantly refers for LEL $(p<0.0001)$. The prediction rate for the true embryonic loss was $31.8 \%$ when OD cutoff from $0 \%$ to $+30 \%$ of cutoff was examined while it was $62.5 \%$ when the threshold was OD cutoff of $0 \%$ to $10 \%$ of cutoff. The authors conclude that BioPRYN was useful for prediction of a part of LEL in dairy cows and serum P4 concentration in these cows related to the rate of LEL.

\section{Introduction}

Extended postpartum interval, poor heat expression, inefficient detection of oestrus and fertilization failure are major causes of reproductive inefficiency; but early embryonic death is recognized as the major cause of reproductive loss in cattle (Sreenan et al. 2001). Ózsvári et al. (2006) analysed the economic data in two Hungarian large-scale Holstein-Friesian dairy farms using the average output and fertility parameters by a partial budgeting method. The data of calved cows and agroeconomic conditions were taken into consideration to quantify the losses. Considering net milk receipts and calf sales, respectively, an average calving interval of 11 months ( $<350$ days) and 12 months were optimal economically. The annual losses due to reproductive failures were 194-276 EUR per cow on the two farms; therefore, the annual economic losses due to reproductive disorders were 160-320 EUR per cow. Early pregnancy detection is one of the key solutions for the decreasing of calving interval. Common methods are (i) rectal palpation [35-42 days post-insemination (PI)], (ii) B-mode ultrasonography (25-30 days PI) and (iii) examination of pregnancy-specific proteins [PSPB; pregnancy associated glycoprotein (PAG), 29-30 days $\mathrm{PI}$ ] in cattle. BioPryn ${ }^{\mathrm{TM}}$, an enzyme-linked immunosorbent assay (ELISA) test has been developed and is distributed for the detection of PSPB in the circulation of pregnant cows. In three experiments BioPryn ${ }^{\mathrm{TM}}$ was evaluated and was found to be a practical, reliable and safe system for pregnancy detection in dairy cattle. The BioPryn $^{\mathrm{TM}}$ was also examined for the prediction of the embryonic loss between days 30 and 36 after artificial insemination (AI) (Gábor et al. 2004).

In first-service heifers, the fertilization rate (FR) may approach $100 \%$. Fertility losses in these animals are between $40 \%$ and $45 \%$ by $17-19$ days after insemination. In repeat breeder heifers, losses occur because of fertilization failure (FR 70\%) and embryonic mortality that are $30-35 \%$ in the same period. The major portion of loss occurs before day 15 after service (Ayalon 1978); therefore, the embryo dies before interferon tau is released to prevent prostaglandin induced luteal regression. Such cows will return to oestrus after the same interval as unmated animals, despite their having been pregnant (Ayalon 1978). The critical period appears to be soon after the embryo enters the uterus, 6-7 days after service, when the morula is developing into the blastocyst. Lamming and Royal (2001) reported an early embryonic loss from $24 \%$ to $40 \%$, highlighting the importance of embryo mortality to the dairy industry.

Pregnancy detection by BioPryn ${ }^{\mathrm{TM}}$ is routinely used in the author's laboratory in Hungary. Approximately 10000 tests are performed per year and the results are reported to the farm owners. For all cows of this study, re-check of the assay result by palpation at 60 days is also performed as a routine tool. Differences in pregnancy status for cows between the early assay results and 60 days were referred to as late embryonic loss (LEL). Alexander et al. (1995), using presence of PSPB as measured by radioimmunoassay, found that from 30 to 45 days after AI until 60 days, there was a $5.4 \%$ embryo loss in first-bred dairy heifers. The losses in multi-parous cows are expected to be greater. It is also expected to be greater if time of first measure is reduced to $30-36$ days (as is the case in this study). Prediction of embryonic loss by observation of the optical density (OD) response in a test sample on a given day after AI would be of value in dairy management. A low OD would be a reflection of low PSPB in the sample. If it were lower than normal, embryo growth may be retarded resulting in embryo death.

The objective of the present study was to develop a means for prediction of embryonic loss at the time of early pregnancy detection (approximately 30-36 days PI) by serum PSPB and serum progesteron (P4) assays.

\section{Material and Methods}

Over a 25-month period, blood samples were collected and assayed for the presence of serum PSPB and 
concentration of P4 on three Hungarian, large-scale dairy farms (Farm A, Farm C and Farm E). Blood samples were collected 30-36 days after insemination and were sent by overnight mail to the laboratory. The blood samples were immediately centrifuged and the serum was cooled in refrigerator $\left(4-5^{\circ} \mathrm{C}\right)$. Pregnancy was checked by BioPRYN assay (BioTracking LLC, Moscow, ID, USA). BioPRYN provides a yes or no pregnancy result. If the OD reading for a sample exceeds a cutoff OD, the animal is called pregnant. If it is less she is called open or not pregnant. The cutoff is calculated from the OD values of triplicate test wells for two PSPB standards. The cutoff $\mathrm{OD}$ is equivalent to $0.024 \mathrm{ng}$ of PSPB in the test well. This value was measured by a well-documented radioimmunoassay (Sasser et al. 1986) for PSPB.

Samples from all cows that tested not pregnant (open) were tested for serum P4 concentration to determine the status of the cycle and then to determine the appropriate treatment for the open cows. Cows with high serum progesterone were assigned as in cycle with a corpus luteum and received a single prostaglandin $\mathrm{F}_{2 \alpha}\left(\mathrm{PGF}_{2 \alpha}\right)$ treatment. Those with low serum progesterone were assigned as non-cycling without a corpus luteum and were given the Ovsynch treatment to induce a new cycle (GnRH injection on days 0 and 9 and $\mathrm{PGF}_{2 \alpha}$ on day 7 , timed AI 16-24 h after the second GnRH injection).

There were 11807 inseminations this period. Blood was collected between 30-36 days after AI (day of AI $=0$ ) from 8118 cows and 4085 were found to be pregnant. Embryo loss was determined by rectal palpation at 60 days after AI.

\section{Animals \\ Crossbred Holstein-Friesian cows aged 2.1-13.7 years (mean $4.2 \pm 1.7$ years) were bred within the experi- mental period. Cows had calved $1-11$ times (mean $2.2 \pm 1.4$ ) and number of AI services ranged from 1 to 15 (mean $2.7 \pm 2.0$ ). Mean annual milk production of the three herds ranged from 7800 to $9500 \mathrm{~kg}$ per cow in this period.}

\section{Examination of the serum P4 concentration}

The P4 test was applied to serum samples from all cows that tested open by BioPRYN. In addition, it was applied to samples from cows with an OD reading in the BioPRYN test that was between $0 \%$ and $30 \%$ above the cutoff OD value. P4 was assayed with an ELISA test (QuantiCheck, Veterinorg Ltd., Budapest, Hungary). Cows were partitioned in three categories by $\mathrm{P} 4$ concentration: high $(>4 \mathrm{ng} / \mathrm{ml})$, medium $(2-4 \mathrm{ng} / \mathrm{ml})$ and low $(<2 \mathrm{ng} / \mathrm{ml})$. The authors predicted a presumed (low) or possible (medium) embryonic loss or maintenance of the pregnancy (high). The process for prediction of embryonic loss is shown in Fig. 1, as is the treatment methods for open cows and cows returning to oestrus.

\section{Artificial insemination and hormonal treatments}

All cows were bred by intra-cervical AI 30-586 days postpartum. Some had been synchronized for oestrus prior to breeding with Ovsynch $(\mathrm{n}=712$; Gabor et al. 2002), Provsynch $(\mathrm{n}=95$; Thatcher et al. 2001) protocol or single $\mathrm{PGF}_{2 \alpha}$ injection $(\mathrm{n}=591)$, while the remaining cows $(n=2687)$ did not receive any treatment before AI.

\section{Analysing data}

Data were analysed by S-Plus 2000 (MathSoft Inc 1999). The BioPRYN OD values were sorted by rank from $0 \%$ to $30 \%$ above the cutoff and where a P4 level within one of the three categories had also been determined. Contingency tables were developed and scored by Pearson's chi-square test (or Fisher's Exact test where number of cases were $<5$ ).

\section{Results}

A total 8118 blood samples were analysed between 30 and 36 days post-AI. There were 4085 pregnant animals and $9.6 \%$ were tested with the P4 assay. The number of pregnant cows on the three farms is shown in Table 1. Moreover included are LELs between the 30-36 and 60 days of pregnancy. A total of 710 LELs were detected $(17.4 \%)$ and $31.8 \%$ of them were predicted because of a low OD value at 30-36 days after AI. In Table 1 the prediction rate has been compared between farms and it proved to be significantly different $(\mathrm{p}<0.001)$. The LEL ratio was also different $(\mathrm{p}<0.001)$.

Table 2 shows the prediction of LEL when a low OD value from the BioPRYN assay was partitioned into the two categories (OD cutoff $+10 \%$ or $+30 \%$ ) and then partitioned within the three $\mathrm{P} 4$ groups. There was a significant $(\mathrm{p}<0.001)$ difference in true prediction of LEL when grouped by $\mathrm{P} 4$ concentration. Comparing the proportions between the thresholds (OD cutoff $+10 \%$ or $+30 \%)$, there was no significant difference $(\mathrm{p}=$ $0.741,0.792$ and 0.676 , respectively, for low, medium and high $\mathrm{P} 4$ level).

The $62.5 \%$ of the possible embryonic loss was predicted if PSPB cutoff $+10 \%$ was used for analysing the OD data and further $30 \%$ was added when PSPB cutoff $+30 \%$ was used as threshold (Table 2 ). Increasing the threshold by $20 \%$ resulted 152 extra P4 analyses and the prediction of 76 plus embryonic losses (prediction in this range was $50 \%$ respectively). Effectiveness of the LEL prediction in cows with low $(<2 \mathrm{ng} / \mathrm{ml}) \mathrm{P} 4$ serum concentration was rather high (84.6-95.1\%), while with medium $(2-4 \mathrm{ng} / \mathrm{ml})$ serum P4 serum concentration was lower (53.9-59.8\%). Probability of maintaining pregnancy was rather high in cows with $>4 \mathrm{ng} / \mathrm{ml}$ serum progesterone concentration (59.5$74.0 \%)$.

Table 3 shows that the mean overall prediction rate for embryonic loss is $57.7 \%$ and was no difference among the farms in prediction of the loss. Prediction was most reliable in the low P4 category in all farms $(87$ predicted of 80 true). In the medium P4 category, there were some differences for predicted vs true among the farms (A: $61.7 \%$; B: $55.8 \%$; C: $54.1 \%$ ). Prediction of embryonic loss (predicted vs true) in the high P4 category was above $63.0 \%, 69.5 \%$ and $61.8 \%$ (Farm $\mathrm{A}, \mathrm{C}$ and E respectively). 
Fig. 1. The prediction process for embryonic loss and for the treatment methods of open cows and cows returning in oestrus

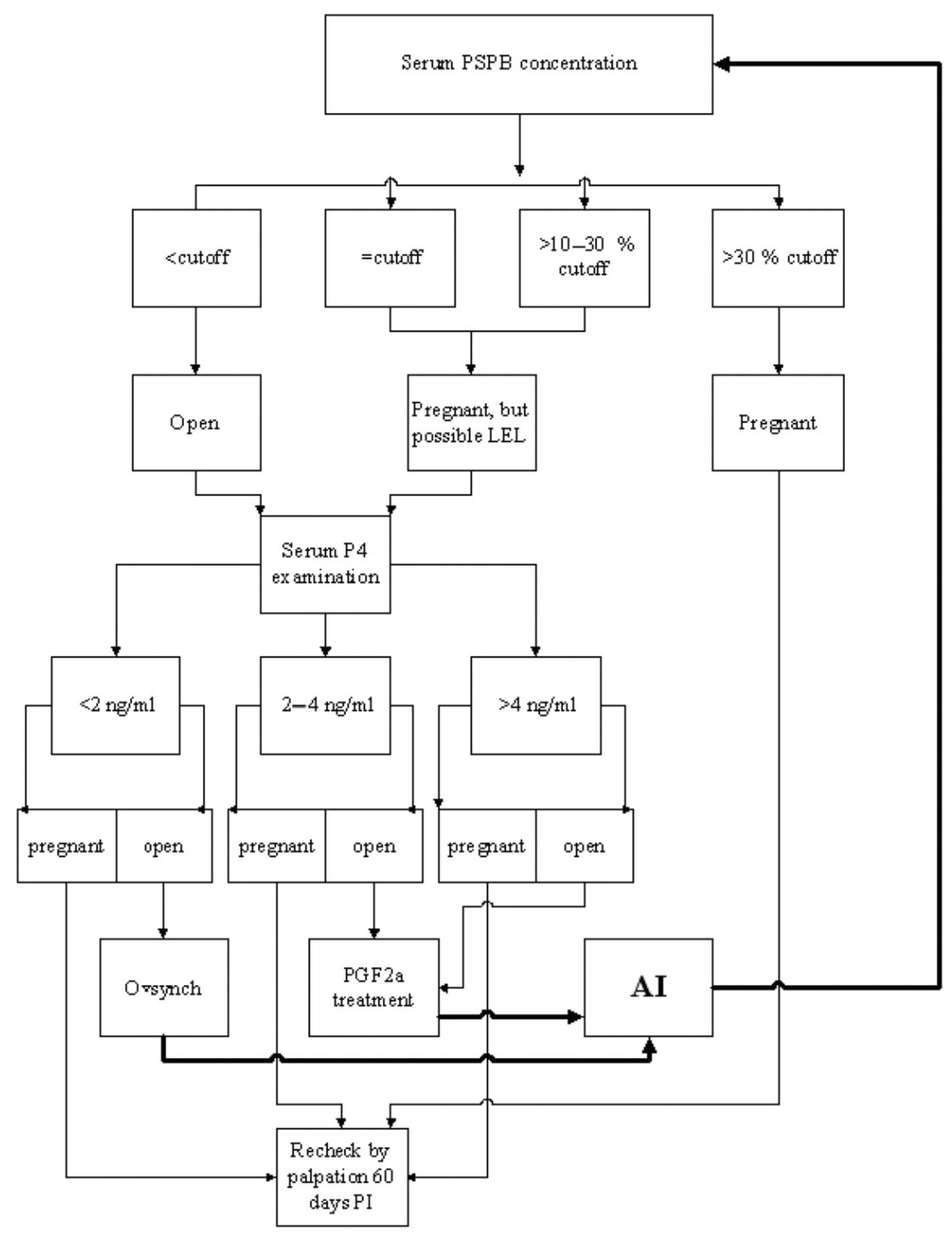

Table 1. Number of predicted and non-predicted embryonic loss in different farms

\begin{tabular}{|c|c|c|c|c|c|c|}
\hline & Pregnant & $\begin{array}{l}\text { True } \\
\text { LEL }\end{array}$ & $\begin{array}{c}\text { LEL } \\
\%\end{array}$ & $\begin{array}{l}\text { Non- } \\
\text { predicted } \\
\text { LEL }\end{array}$ & $\begin{array}{c}\text { Predicted } \\
\text { true } \\
\text { LEL }\end{array}$ & $\begin{array}{c}\text { Prediction } \\
\%\end{array}$ \\
\hline Farm A & 1534 & 323 & 21.0 & 248 & 76 & 23.5 \\
\hline Farm C & 1180 & 185 & 15.7 & 124 & 61 & 32.9 \\
\hline Farm E & 1371 & 202 & 14.7 & 113 & 89 & 44.1 \\
\hline Total & 4085 & 710 & 17.4 & 485 & 226 & 31.8 \\
\hline
\end{tabular}

LEL, late embryonic loss.

There was no significant difference between farms (Table 3) in the true prediction rates. There was significant difference $(p<0.001)$ between the low, medium and high P4 levels for each farm, so the true prediction rates are the same in the different farms.

Table 4 shows the embryonic losses after AI in groups with various hormone treatments or nontreated. The embryonic loss was higher $(18.7 \%)$ in the groups treated by Ovsynch or non-treated $(17.4 \%)$ and was lower in groups treated by Provsynch or a single $\mathrm{PGF}_{2 \alpha}$ treatment $(15.8 \%$ and $15.9 \%)$. There was no difference among the four groups (chi-square, $\mathrm{p}=0.59)$.

\section{Discussion}

In the current examinations the pregnancy rate $(34.5 \%)$ was higher at the time of early pregnancy detection than at time of rectal palpation $(28.6 \%)$. The later was similar to the national mean $(29.1 \%)$ when examined by palpation. Level of milk production in these farms may have affected the results, compared with the national average, as it was higher than the average milk production in the Hungarian Holstein-Friesian breed $(9005 \mathrm{~kg}$ vs $7646 \mathrm{~kg})$. The difference between early pregnancy and rectal palpation represents the LEL and was $17.4 \%$. This was similar to results of Humblot (2001) $(14.7 \%)$; in high production milking cows. The LEL data vary among the different farms.

The prediction rate for the true embryonic loss was $31.8 \%$ when OD cutoff from $0 \%$ to $+30 \%$ of cutoff was examined while it was $62.5 \%$ when the threshold was OD cutoff of $0 \%$ to $10 \%$ of cutoff. This would require about 392 extra $\mathrm{P} 4$ examinations $(9.6 \%$ of all pregnant 


\begin{tabular}{|c|c|c|c|c|c|c|}
\hline \multirow[b]{2}{*}{$\begin{array}{l}\text { Serum P4 } \\
\text { concentration }\end{array}$} & \multicolumn{2}{|c|}{ PSPB cutoff $+10 \%$} & \multicolumn{2}{|c|}{ PSPB cutoff $+30 \%$} & \multicolumn{2}{|c|}{$\begin{array}{c}\text { Difference between } 10 \% \\
\text { and } 30 \%\end{array}$} \\
\hline & $\begin{array}{c}\text { Embryonic } \\
\text { loss }\end{array}$ & $\begin{array}{c}\text { Predicted } \\
\%\end{array}$ & $\begin{array}{c}\text { Embryonic } \\
\text { loss }\end{array}$ & $\begin{array}{c}\text { Predicted } \\
\%\end{array}$ & $\begin{array}{c}\text { Embryonic } \\
\text { loss }\end{array}$ & $\begin{array}{c}\text { Predicted } \\
\%\end{array}$ \\
\hline Low $<2 \mathrm{ng} / \mathrm{ml}$ & 58 & $95.1^{\mathrm{c}}$ & 80 & $92.0^{\mathrm{c}}$ & 22 & 84.6 \\
\hline Medium $2-4 \mathrm{ng} / \mathrm{ml}$ & 58 & $59.8^{\mathrm{d}}$ & 99 & $57.2^{\mathrm{d}}$ & 41 & 53.9 \\
\hline High $>4 \mathrm{ng} / \mathrm{ml}$ & 34 & $41.5^{\mathrm{f}}$ & 47 & $35.6^{\mathrm{f}}$ & 13 & 26.0 \\
\hline Total & $150^{\mathrm{a}}$ & 62.5 & $226^{\mathrm{b}}$ & 57.6 & 76 & 50.0 \\
\hline
\end{tabular}

Table 2. Predictive value of the PSPB cutoff $(+10 \%$ and $/$ or $30 \%)$ for the embryonic loss in relationship with the serum $\mathrm{P} 4$ concentration

Values within rows not sharing a common superscript differ significantly $(\mathrm{p}<0.001)$.

Table 3. Number of predicted and true embryonic losses and their relations to the different $\mathrm{P} 4$ categories on the different farms (threshold PSPB cutoff $+30 \%$ )

\begin{tabular}{|c|c|c|c|c|c|c|c|c|}
\hline & \multicolumn{8}{|c|}{ Progesterone level } \\
\hline & \multicolumn{2}{|c|}{ Low } & \multicolumn{2}{|c|}{ Medium } & \multicolumn{2}{|c|}{ High } & \multicolumn{2}{|c|}{ Embryonic loss } \\
\hline & Predicted & True & Predicted & True & Predicted & True & $\begin{array}{l}\text { Total } \\
\text { true }\end{array}$ & $\begin{array}{c}\text { Prediction } \\
\%\end{array}$ \\
\hline Farm A & 17 & $16^{\mathrm{a}}$ & 60 & $37^{\mathrm{b}}$ & 62 & $23^{\mathrm{c}}$ & 76 & 54.7 \\
\hline Farm C & 23 & $21^{\mathrm{a}}$ & 52 & $29^{\mathrm{b}}$ & 36 & $11^{\mathrm{c}}$ & 61 & 55 \\
\hline Farm E & 47 & $43^{\mathrm{a}}$ & 61 & $33^{\mathrm{b}}$ & 34 & $13^{\mathrm{c}}$ & 89 & 62.7 \\
\hline Total & 87 & 80 & 173 & 99 & 132 & 47 & 226 & 57.7 \\
\hline
\end{tabular}

Values within rows not sharing a common superscript differ significantly $(\mathrm{p}<0.001)$.

Table 4. Effect of different synchronization protocols on embryonic loss

\begin{tabular}{|c|c|c|c|c|}
\hline & Ovsynch & Provsynch & $\mathrm{PGF}_{2 \alpha}$ & Non-treated control \\
\hline No. pregnancy & 712 & 95 & 591 & 2687 \\
\hline No. embryonic loss & 133 & 15 & 94 & 468 \\
\hline $\begin{array}{l}\text { Percentage of } \\
\text { embryonic loss }\end{array}$ & $18.7^{\mathrm{a}}$ & $15.8^{\mathrm{a}}$ & $15.9^{\mathrm{a}}$ & $17.4^{\mathrm{a}}$ \\
\hline
\end{tabular}

Values within rows not sharing a common superscript differ significantly.

samples). By increasing the threshold by $20 \%, 76$ more embryonic losses were predicted and this supports using higher threshold for the detection of LEL. Humblot et al. (1988) stated that PSPB serum concentration 30 days after AI (measured by RIA) could not differentiate the pregnant cows and cows with LEL, even if these results were combined with serum P4 test. In our examinations the time of the PSPB test was 30-36 days PI and we found that the BioPRYN, with OD an indicator of PSPB level, and P4 could find LEL. Thus it would find open cows sooner. Lower PSPB serum level significantly refers to LEL $(p<0.0001)$. Most of the cows with low serum PSPB level and have $<2 \mathrm{ng} / \mathrm{ml}$ serum P4 concentration lost the embryo between the first and the second pregnancy check $(\mathrm{p}<0.0001)$. The most effective prediction rate was found in low $\mathrm{P} 4$ category (approximately 90\%) while prediction rate in the medium and high $\mathrm{P} 4$ category varied among the farms.

Ovarian treatments did not affect the LEL significantly.

In summarize the authors conclude that BioPryn ${ }^{\mathrm{TM}}$ was useful for prediction of a part of LEL in dairy cows and serum $\mathrm{P} 4$ concentration in these cows related to the rate of LEL.

\section{References}

Alexander BM, Guardia R, Johnson MS, Van de Graff WL, Senger PL, Sasser RG, 1995: Embryonic loss from 30 to 60 days post-breeding and effect of rectal palpation for pregnancy. Theriogenology 43, 551-556.

Ayalon N, 1978: A review of embryonic mortality in cattle. J Reprod Fertil 54, 483-493.

Gabor G, Kastelic JP, Pinter S, Szasz F, Szigeti E, Solymosi N, 2002: Improving reproductive performance in lactating dairy cows by synchronizing ovulation or inducing estrus. Acta Vet Hung 50, 231-234.

Gábor G, Tóth F, Szász F, 2004: Influence of synchronized ovulation and pre-synchronization on pregnancy rates used timed AI in lactating dairy cows. In: Abstract book of the 15th International Congress on Animal Reproduction, Published by Brazilian College of Animal Reproduction, Proto Seguro, Brasil 2004, Vol. 2, 338.

Humblot P, 2001: Use of pregnancy specific proteins and progesterone assays to monitor pregnancy and determine the timing, frequencies and sources of embryonic mortality in ruminants. Theriogenology 56, 1417-1433.

Humblot P, Camous J, Martal J, Charlery J, Jeanguyot N, Thibier M, Sasser RG, 1988: Pregnancy-specific protein B, progesterone concentrations and embryonic mortality during early pregnancy in dairy cows. J Reprod Fertil 83, 215-223.

Lamming GE, Royal MD, 2001: Ovarian hormone patterns and subfertility in dairy cows. In: Diskin MG (ed.), Fertility in the High-Producing Dairy Cows, Vol. 1. BSAS Occasional Pub. 26, pp. 105-118.

MathSoft Inc, 1999: S-Plus 2000 User's Guide. Data Analysis Products Division, Seattle, WA, USA.

Ózsvári L, Tóth F, Gábor G, 2006: The financial importance of reproduction management in dairy herds. Reprod Domest Animals 41 No4: Abs P148, 346 pp.

Sasser RG, Ruder CA, Ivani KA, Butler JE, Hamilton WC, 1986: Detection of pregnancy by radioimmunoassay of a novel pregnancy-specific protein in serum of cows and a profile of serum concentrations during gestation. Biol Reprod 35, 936-942.

Sreenan JM, Diskin MG, Morris DG, 2001: Embryo survival rate in cattle: a major limitation to the achievement of high fertility.

Thatcher WW, Moreira F, Santos JEP, Mattos RC, Lopes FL, Pancarci SM, Risco CA, 2001: Effects of hormonal treatments on reproductive performance and embryo production. Theriogenology 55, 75-89.

Submitted: 29.08 .2006

Author's address (for correspondence): Dr G Gábor, Research Institute for Animal Breeding and Nutrition, Gesztenyes Str 1, Herceghalom 2053, Hungary. E-mail: h12617gab@helka.iif.hu 